\title{
Effect of Hydroxypropyl Methylcellulose-Beeswax Composite Edible Coatings Formulated with or without Antifungal Agents on Physicochemical Properties of Plums during Cold Storage
}

\author{
Sule Gunaydin, ${ }^{1}$ Hakan Karaca, ${ }^{1}$ Lluís Palou, ${ }^{2}$ \\ Beatriz de la Fuente, ${ }^{2}$ and María B. Pérez-Gago ${ }^{2}$ \\ ${ }^{1}$ Department of Food Engineering, Faculty of Engineering, Pamukkale University, Camlik, 20070 Denizli, Turkey \\ ${ }^{2}$ Centre de Tecnologia Postcollita (CTP), Institut Valencià d'Investigacions Agràries (IVIA), Apartat Oficial, Montcada, \\ 46113 Valencia, Spain \\ Correspondence should be addressed to María B. Pérez-Gago; perez_mbe@gva.es
}

Received 15 June 2017; Accepted 31 July 2017; Published 11 September 2017

Academic Editor: A. Lopez-Rubio

Copyright (c) 2017 Sule Gunaydin et al. This is an open access article distributed under the Creative Commons Attribution License, which permits unrestricted use, distribution, and reproduction in any medium, provided the original work is properly cited.

\begin{abstract}
The influence of hydroxypropyl methylcellulose- (HPMC-) beeswax (BW) composite edible coatings formulated with or without food additives with antifungal properties on physicochemical and sensory properties of plums (Prunus salicina) cv. "Friar" stored for 11 and $22 \mathrm{~d}$ at $1^{\circ} \mathrm{C}$ followed by a shelf life period of $5 \mathrm{~d}$ at $20^{\circ} \mathrm{C}$ was evaluated. Food preservatives selected from previous research included potassium sorbate (PS), sodium methyl paraben (SMP), and sodium ethyl paraben (SEP). Emulsions had 7\% of total solid content and were prepared with glycerol and stearic acid as plasticizer and emulsifier, respectively. All the coatings reduced plum weight and firmness loss and coated fruit showed higher titratable acidity, soluble solids content, and hue angle values at the end of the storage period. In addition, physiological disorders such as flesh browning and bleeding were reduced in coated samples compared to uncoated controls. Paraben-based coatings were the most effective in controlling weight loss and the SMP-based coating was the most effective in maintaining plum firmness. Respiration rate, sensory flavor, off-flavors, and fruit appearance were not adversely affected by the application of antifungal coatings. Overall, these results demonstrated the potential of selected edible coatings containing antifungal food additives to extend the postharvest life of plums, although further studies should focus on improving some properties of the coatings to enhance gas barrier properties and further increase storability.
\end{abstract}

\section{Introduction}

Postharvest fruit coating is a common practice used for many years by the industry commercializing different fresh commodities. The main objectives of this practice are extending shelf life by limiting the respiration and water loss rates and improving the visual quality of the product. Traditionally, lipid-based coatings based on waxes and resins are used for this aim since they provide a good moisture barrier and give an additional shine to the fruit [1]. However, lipid-based coatings are brittle and have poor mechanical properties [2]. At present, research efforts on postharvest coating treatments are steadily increasing towards new coating formulations based on biopolymers such as polysaccharides and proteins that can be safely consumed while contributing to meet consumer's interest in health, nutrition, and food safety.
These hydrocolloids generally form a continuous structured film with superior mechanical properties and oxygen barrier properties compared to lipid-based coatings but present a low barrier to moisture due to their hydrophilic character $[3,4]$. For this reason, composite edible coatings based on matrixes of polysaccharides or proteins and lipids are formulated to obtain coatings with superior mechanical and barrier properties [5]. Besides these main ingredients, several other compounds such as plasticizers, emulsifiers, antimicrobials, texture enhancers, antioxidants, flavoring agents, and nutrients can be included in coating formulations to improve coating integrity and emulsion stability and enhance functionality $[6,7]$.

In the last decades, the development of antimicrobial edible films and coatings has emerged as a new, effective, and environmentally friendly alternative mean to extend 
the shelf life of many products including fresh fruits and vegetables. By protecting fruit from postharvest decay caused by deleterious microorganisms, these coatings provide extra functions beyond retarding fruit dehydration and reducing fruit respiration rate and ethylene production. Compounds as essential oils, organic and inorganic acids and their salts, and other permitted food additives or generally recognized as safe (GRAS) compounds have been preferred as active ingredients of antifungal edible coatings for fruits and vegetables [8-12]. These coatings are of particular interest for fruits that are not peeled for consumption and have emerged as an important alternative to the use of synthetic chemical fungicides for postharvest disease control. For instance, they could substitute synthetic waxes amended with conventional fungicides in the case of commodities such as citrus, pome fruits, stone fruits, or many tropical fruits, and they could also be of use in the case of fresh commodities such as berries, tomato, persimmon, or pomegranate, among others, to which the application of postharvest fungicide treatments is not currently allowed in the vast majority of producing countries [13].

Plums are climacteric fruits with relatively short postharvest life, usually limited by a high susceptibility to internal breakdown, loss in texture, and postharvest diseases caused by a number of fungal pathogens [14-16]. The market life of these fruit varies with the cultivar and storage conditions typically between 1 and 8 weeks $[14,15]$. Storage at $0-1^{\circ} \mathrm{C}$ and 90-95\% relative humidity $(\mathrm{RH})$ has been recommended to extend the postharvest life of plums [17], but in some cases cold storage is not sufficient to significantly extend shelf life due to the appearance of chilling injury symptoms. Conversely, storage at higher temperatures can favor the development of fungal infections and increase the incidence of postharvest diseases. Technologies such as controlled and modified atmosphere packaging [18], treatment with chemicals such as oxalic acid [19] and 1-methyl cyclopropene (1-MCP) [20], and the application of edible coatings, all in combination with cold storage, have been tested for prolonging the postharvest life of plums in recent years.

Several works in the literature report that edible coatings based on whey protein [21], hydroxypropyl methylcellulose (HPMC) [2, 14, 22], alginate [23], and chitosan [24-26] preserved the postharvest quality of plums by maintaining fruit firmness and reducing weight loss, internal breakdown and respiration, and decay rates of coated plums. The effect of these coatings on weight loss, firmness, and internal breakdown greatly depended on coating composition. Thus, the addition of beeswax (BW) as a natural lipid was required to improve the moisture barrier on plums treated with HPMC coatings $[14,22]$, whereas the effect of these coatings on fruit firmness and volatile content greatly depended on HPMC content and plasticizer type and content [2]. Similarly, coatings formulated with essential oils as antimicrobial agents were recently tested on plum fruit and, depending on the type of essential oil and its concentration, successful results and good effects on plum quality attributes were obtained $[27,28]$. In other fruits such as citrus and cherry tomatoes, the addition of organic acid salts to HPMC-based coatings to control mold growth affected the gas and moisture barrier of the coatings and the quality of coated fruit during cold storage $[29,30]$.

In previous studies, we evaluated a wide variety of common food preservatives (mineral salts, organic acid salts, paraben salts, and other GRAS compounds) as ingredients of HPMC-BW edible coatings against brown rot disease caused by Monilinia fructicola on artificially inoculated plums [8]. Among all the antifungal agents tested, parabens and potassium sorbate were found to be the best for effective control of disease severity and incidence, respectively. Although several research works on postharvest coating of plums were conducted in the past, the number of studies investigating the effects of coatings containing antimicrobial agents on the physicochemical properties of plums is very limited. Moreover, to the best of our knowledge, there are no previous studies concerning the potential effects of organic acids and their salts incorporated into coating formulations on quality attributes of plums. The objective of this work was to investigate the effect of potassium sorbate and parabens as ingredients of HPMC-BW edible composite coatings on physicochemical and sensory properties of "Friar" plum fruit stored up to 22 days at $1^{\circ} \mathrm{C}$, followed by simulated commercialization period of 5 days at $20^{\circ} \mathrm{C}$.

\section{Materials and Methods}

2.1. Edible Coating Formulation. The coatings used in the study consisted of a hydrophilic phase (HPMC; Methocel E15; Dow Chemical Co., Midland, MI, USA) and a hydrophobic phase (BW; Grade 1, Fomesa Fruitech S.L., Valencia, Spain). Glycerol and stearic acid (Panreac-Química S.A., Barcelona, Spain) were added to the formulation to serve as plasticizer and emulsifier, respectively. All the formulations contained $36 \%$ BW (dry basis, db), constant ratios of HPMC-glycerol $(3: 1, \mathrm{db})$ and BW-stearic acid $(5: 1, \mathrm{db})$, and a total solid content of $7 \%$. For emulsion preparation, an aqueous solution of HPMC $(5 \%, w / w)$ was prepared by dispersing HPMC in water at $90^{\circ} \mathrm{C}$ and later hydrating at $20^{\circ} \mathrm{C}$. BW, glycerol, stearic acid, and water were added to the HPMC solution and this mixture was heated above $90^{\circ} \mathrm{C}$ to achieve complete melting of the lipids. Samples were then homogenized using a high-shear mixer (Ultra-Turrax model T25, IKA-Werke, Steufen, Germany) for $1 \mathrm{~min}$ at 12,000 rpm followed by $3 \mathrm{~min}$ at $22,000 \mathrm{rpm}$. Emulsions were cooled under agitation to a temperature below $25^{\circ} \mathrm{C}$ by placing them in a water bath while maintaining agitation for $25 \mathrm{~min}$ to ensure complete hydration of HPMC. Finally, potassium sorbate (PS), sodium methylparaben (SMP), or sodium ethylparaben (SEP) (Merck KGaA, Darmstadt, Germany) were added to the emulsions under magnetic agitation to achieve final concentrations of $1 \%$ PS or $0.1 \%$ SMP or SEP in the coating formulations. These antifungal agents and their concentrations had been previously selected as the most effective in controlling brown rot on inoculated plums [8]. Viscosity and $\mathrm{pH}$ values of the emulsions were measured with a viscosimeter (Visco Star Plus R, Fungilab S.A., Barcelona, Spain) and a pH-meter (Consort C830 multiparameter analyzer, Turnhout, Belgium), respectively. Formulations were kept for $24 \mathrm{~h}$ at $5^{\circ} \mathrm{C}$ before use. The emulsions were checked for stability according to the method 
described by Valencia-Chamorro et al. [11], observing no phase separation after $24 \mathrm{~h}$ at $25^{\circ} \mathrm{C}$.

2.2. Fruit and Coating Application. Plums (Prunus salicina Lindl.) cv. "Friar" were supplied by Cooperativa del Camp de Llutxent-Otos S.C.V. (Llutxent, Vall d'Albaida, Valencia, Spain). Fruit were commercially grown and no postharvest treatments were applied. After arrival to the laboratory, fruit were examined for various sorts of external damage, surfacesanitized for $4 \mathrm{~min}$ with a diluted bleach solution $(0.5 \%$ sodium hypochlorite), rinsed in tap water, and air-dried for $24 \mathrm{~h}$ at room temperature $\left(23-25^{\circ} \mathrm{C}\right)$. Then, plums were randomly divided into 10 groups of 50 fruit each, which corresponded to five different treatments and two different storage periods. Uncoated fruit and fruit coated with coatings formulated without the addition of antimicrobial agents were designated as Control A and Control B, respectively. The other three treatments corresponded to coating formulations containing PS, SMP, or SEP as antifungal ingredients. Plums were coated individually as described by Bai et al. [31]. For this aim, $300 \mu \mathrm{L}$ of emulsion was pipetted onto each fruit and rubbed manually to mimic the application of industrial coating machinery in fresh produce packing-lines. Coated fruit were drained on a mesh screen and allowed to air-dry at room temperature. Coated fruit and control samples were then placed on plastic trays on corrugated cartons and stored up to 22 days at $1^{\circ} \mathrm{C}$ and $90 \% \mathrm{RH}$. In order to simulate industrial storage and retail conditions, physicochemical and sensory analyses were conducted at harvest, after 11 and $22 \mathrm{~d}$ of storage at $1^{\circ} \mathrm{C}$, and after a shelf life period of $5 \mathrm{~d}$ at $20^{\circ} \mathrm{C}$.

\subsection{Effect of the Coatings on Fruit Quality}

2.3.1. Weight Loss. Weight loss during storage was determined by individually weighing 20 fruits per treatment at the beginning and the end of each storage period with an analytical balance. Results were expressed as the percentage of initial weight loss.

2.3.2. Fruit Flesh Firmness. Fruit flesh firmness was measured using an Instron Universal Testing Machine (Model 4301, Instron Limited, Bucks, UK). A thin disk of the skin of about $2 \mathrm{~cm}$ in diameter was removed from each of the opposite cheeks of the fruit and firmness was determined as the maximum force in Newtons $(\mathrm{N})$ required to penetrate the fruit flesh with a plunger of $8 \mathrm{~mm}$ diameter. Twenty plums were used per treatment and average values were calculated.

2.3.3. Peel Color. Surface color of 20 plums per treatment was measured with a colorimeter (Model CR-400, Minolta, Tokyo, Japan) using the CIELAB color parameters $L^{*}, a^{*}, b^{*}$, chroma $\left(C^{*}\right)$, and hue angle $\left(h^{\circ}\right)$. Each measurement was taken at three different locations of the fruit. $C^{*}$ and $h^{\circ}$ values were calculated according to the formula given below.

$$
\begin{aligned}
\text { Chroma }\left(C^{*}\right) & =\left\lfloor\left(a^{*}\right)^{2}+\left(b^{*}\right)^{2}\right\rfloor^{1 / 2}, \\
\text { Hue }\left(h^{\circ}\right) & =\arctan \left(\frac{b^{*}}{a^{*}}\right) .
\end{aligned}
$$

2.3.4. Internal Quality. The assessed internal quality attributes were soluble solids content (SSC), titratable acidity (TA), and maturity index (MI) of the plum juice. SSC was measured with a digital refractometer (Model PR1, Atago Co. Ltd., Tokyo, Japan) and values were expressed as g sucrose per $100 \mathrm{~mL}$ of juice. TA acidity was determined by titrating $5 \mathrm{~mL}$ of juice with $0.1 \mathrm{M}$ sodium hydroxide to an end point of $\mathrm{pH}$ 8.1 using an automatic titrator (Model T50, Mettler Toledo, Greifensee, Switzerland) and results were expressed as g malic acid equivalent per $100 \mathrm{~mL}$ of juice. MI was calculated as the ratio between SSC and TA. For each treatment, three juice samples from 10 fruit each were prepared and three different readings were performed. Average values were expressed as mean \pm standard error of the mean.

2.3.5. Physiological Disorders. A total of 30 samples per treatment, which corresponded to 3 replicates of 10 fruit each, were examined for the main postharvest physiological disorders of plums. These are caused by chilling injury and their main symptoms are flesh browning and/or bleeding [32]. Fruit were halved and the mesocarp and the area around the pit were visually inspected for browning and bleeding at the end of storage periods at $20^{\circ} \mathrm{C}$. Samples were rated on a scale ranging from 1 (none) to 5 (severe) for browning and a scale from 1 (none) to 3 (severe) for bleeding [32]. The severity for each disorder was calculated as an average index of the three replicates. For each replicate, the severity index was calculated as follows:

Index

$$
=\frac{\sum \text { (number of fruits with each scale } * \text { scale) }}{\text { Total number of fruits }} .
$$

2.3.6. Respiration Rate. The effect of coating application on plum respiration rate was measured through a closed system. Five fruits were individually analyzed for each treatment. Samples were weighed and placed in $250 \mathrm{~mL}$ glass jars. Then, the jars were sealed and incubated at $20^{\circ} \mathrm{C}$ for $2 \mathrm{~h}$. After the incubation period, $1 \mathrm{~mL}$ of the gas in the headspace of the jar was withdrawn using a microsyringe and injected into a gas chromatograph (GC) (Thermo Trace, Thermo Fisher Scientific, Inc., Waltham, MA, USA). The GC was equipped with a thermal conductivity detector (TCD) and fitted with a Poropack QS 80/100 column $(1.2 \mathrm{~m} \times 0.32 \mathrm{~cm}$ i.d. $)$. Temperatures were 35,115 , and $150^{\circ} \mathrm{C}$ for the oven, injector, and TCD, respectively. The carrier gas was helium with a flow rate of $22 \mathrm{~mL} / \mathrm{min}$. A standard gas mixture of oxygen $\left(\mathrm{O}_{2}\right)$ and carbon dioxide $\left(\mathrm{CO}_{2}\right)(15.0: 2.5 \%)$ was used and the $\mathrm{CO}_{2}$ concentration in the samples was calculated according to the peak areas of the samples and the standard. Results were expressed as $\mathrm{mg} \mathrm{CO}_{2} / \mathrm{kg} \mathrm{h}$.

2.3.7. Ethanol and Acetaldehyde Contents. Ethanol and acetaldehyde concentrations were determined from the headspace of the juice samples by GC. Juice samples $(5 \mathrm{~mL})$ were transferred into glass vials with crimp-top caps and PTFE/silicone septum seals. Samples were frozen and stored at $-18^{\circ} \mathrm{C}$ till analysis. At the time of analysis, the equilibrium 
in the headspace of the vials was achieved by placing them in a water bath at $20^{\circ} \mathrm{C}$ for $1 \mathrm{~h}$, followed by $10 \mathrm{~min}$ at $60^{\circ} \mathrm{C}$. One $\mathrm{mL}$ of the gas in the headspace of the vial was withdrawn using a microsyringe and injected to the GC. The GC was equipped with a flame ionization detector (FID), fitted with a Poropack QS 80/100 (1.2 $\mathrm{m} \times 0.32 \mathrm{~cm}$ i.d.), and used helium as carrier gas at a flow rate of $28 \mathrm{~mL} / \mathrm{min}$. Temperatures were 150 , 175 , and $200^{\circ} \mathrm{C}$ for the oven, injector, and FID, respectively. Analytical standards of ethanol and acetaldehyde were used and their concentrations in the headspace of the juice samples were calculated according to the areas under their peaks. Three replicates of 10 fruit per treatment were analyzed and results were expressed as $\mathrm{mg}$ of volatile compounds per $\mathrm{L}$ of juice.

2.3.8. Sensory Analyses. Sensory analysis was conducted by 10 trained panelists according to the general guidance of ISO 8586:2012 [33] at the end of each storage period. For each treatment, samples from various fruit were portioned, coded with randomly chosen 3 -digit numbers, and served on plastic plates at room temperature. Panelists were requested to use different qualitative scales to rate flavor (from very poor = 1 to optimum $=9$ ), off-flavors (from absence $=1$ to high presence $=5$ ), and firmness (from very low $=1$ to very high $=$ 5) of the samples. The judges had to taste various segments of each sample in order to compensate, as far as possible, for biological variation of the material. Spring water was provided for palate rinsing between samples. External aspect of the fruit was also evaluated using a 3-point scale (bad $=1$, acceptable $=2$, and good $=3$ ).

2.4. Statistical Analysis. Experimental data were subjected to analysis of variance (ANOVA) to determine the significant differences among treatments. Duncan's multiple range test, at a significance level of $P=0.05$, was used to separate means from different treatments. All analyses were performed with the software Statgraphics Plus 5.1 (Statpoint Technologies Inc., Warrenton, VA, USA).

\section{Results and Discussion}

3.1. Fruit Weight Loss. The effect of the different coatings on plum weight loss is shown in Figure 1. As expected, weight loss increased with storage time, reaching a maximum value of $2.48 \%$ in uncoated control samples stored for $22 \mathrm{~d}$ at $1^{\circ} \mathrm{C}$ plus $5 \mathrm{~d}$ at $20^{\circ} \mathrm{C}$. The HPMC-BW coatings, with or without antifungal agents, significantly reduced weight loss compared to control samples, being the coatings containing paraben salts more effective than those containing PS. In previous studies conducted with plums $[22,28]$ and other fruits $[34$, 35 ], cellulose-lipid coatings were also reported to reduce weight loss probably due to the moisture barrier exerted by the lipid ingredients of the coating formulation. In plums, which are in general naturally covered with a continuous wax layer that provides high resistance to water movement across the cuticle, Navarro-Tarazaga et al. [22] reported no differences on weight loss between uncoated and HPMCcoated plums with no lipids, which indicated that, in order to

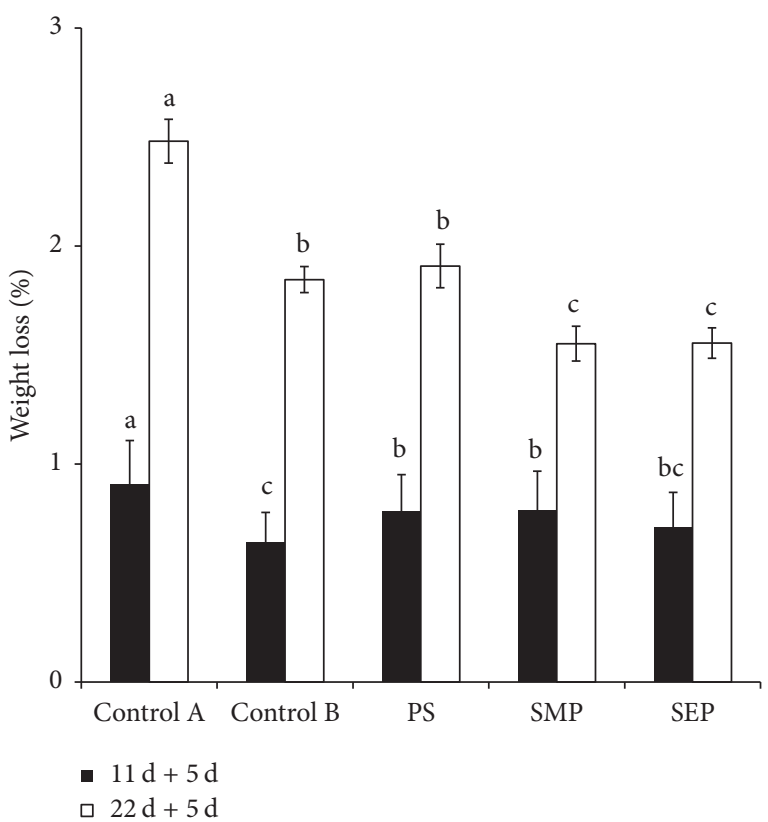

Figure 1: Weight loss of "Friar" plums uncoated or coated with hydroxypropyl methylcellulose-beeswax edible coatings containing potassium sorbate (PS), sodium methyl paraben (SMP), or sodium ethyl paraben (SEP) and stored for 11 and $22 \mathrm{~d}$ at $1^{\circ} \mathrm{C}$ followed by $5 \mathrm{~d}$ at $20^{\circ} \mathrm{C}$. Control A: uncoated; Control B: coating without antifungal agent. For each storage time, bars with different letters are significantly different according to Duncan's range test $(P<0.05)$ $(n=20)$.

improve moisture barrier of plums, coatings must contain a hydrophobic compound.

On the other hand, Valencia-Chamorro et al. [11] reported that the presence of minor ingredients such as food preservatives or GRAS salts in HPMC-lipid edible films had an important effect on their barrier properties, which was attributed to changes in the network structure of the polymer matrix. In that study, HPMC-BW films formulated with paraben salts had lower water vapor permeability than films with organic acid salts like for instance PS. In the present work, the addition of the paraben salts SMP or SEP to the coating matrix had a positive effect for the reduction of weight loss of coated plums, whereas the addition of PS did not modify the moisture barrier properties of the HPMC-BW coating formulated without food preservative (Control B). These observations are in agreement with permeability results reported by Valencia-Chamorro et al. [11]. However, other research works conducted with fresh fruits indicated that the coating performance reducing weight loss did not always correlate with the water vapor permeability of stand-alone films, because physical, physiological, and biochemical properties of the skin and/or the flesh of the fruit have a crucial effect in the coating final performance and they typically show important differences among fruit species and even among cultivars. Thus, for instance, Fagundes et al. [29] observed higher weight loss values on cherry tomatoes coated with HPMC-BW emulsions containing parabens than on fruit 


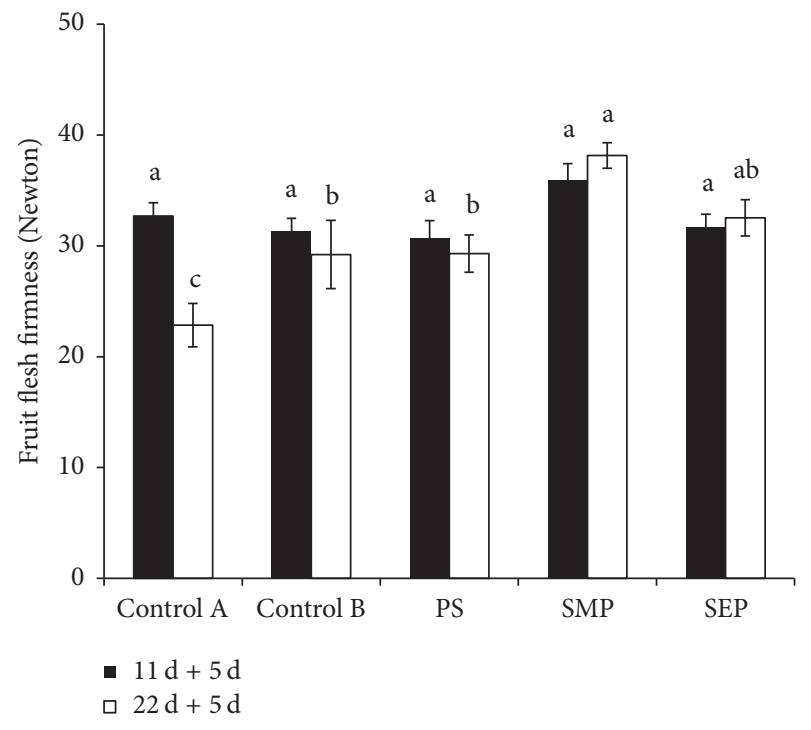

FIGURE 2: Fruit flesh firmness of "Friar" plums uncoated or coated with hydroxypropyl methylcellulose-beeswax edible coatings containing potassium sorbate (PS), sodium methyl paraben (SMP), or sodium ethyl paraben (SEP) and stored for 11 and $22 \mathrm{~d}$ at $1^{\circ} \mathrm{C}$ followed by $5 \mathrm{~d}$ at $20^{\circ} \mathrm{C}$. Firmness at harvest was $47.08 \pm 1.61 \mathrm{~N}$. Control A: uncoated; Control B: coating without antifungal agent. For each storage time, bars with different letters are significantly different according to Duncan's range test $(P<0.05)(n=20)$.

coated with other antifungals such as sodium benzoate. In other works, the influence of HPMC-based coatings containing PS on weight loss of citrus fruits greatly depended on fruit cultivar, and the performance of the coatings was significantly enhanced when PS was used in combination with other organic salts $[30,36]$.

3.2. Fruit Flesh Firmness. Flesh firmness of coated and uncoated samples is shown in Figure 2. Softening is a quality defect that compromises the shelf life and commercialization of many fruits and particularly of plums. For this reason, plums destined for cold storage and/or long-distance transportation are picked with high levels of firmness. In the present work, "Friar" plums were very firm at harvest (47.08 \pm $1.61 \mathrm{~N}$ ), but their firmness significantly decreased during storage to values in the range of $30-38 \mathrm{~N}$ for coated plums and $22 \mathrm{~N}$ for uncoated plums. It is known that polysaccharides present in the cell wall such as pectin, starch, and hemicellulose mainly contribute to the firmness of the fruit. Degradation of these compounds by hydrolyzing enzymes like pectin methylesterase and polygalacturonase causes softening of the fruit during ripening and storage [15]. The capacity of edible coatings to modify the internal gas composition of the fruit in terms of $\mathrm{O}_{2}$ and $\mathrm{CO}_{2}$ concentrations might influence the activities of the cell wall degrading enzymes, reducing fruit softening. In the present study, there were no significant differences among firmness values of uncoated (Control A) and coated samples stored for $11 \mathrm{~d}$ at $1^{\circ} \mathrm{C}$ plus $5 \mathrm{~d}$ at $20^{\circ} \mathrm{C}$ $(P>0.05)$. However, firmness of coated samples (with and without antifungal agents) was significantly higher than that of the uncoated Control A after storage for $22 \mathrm{~d}$ at $1^{\circ} \mathrm{C}$ plus $5 \mathrm{~d}$ at $20^{\circ} \mathrm{C}(P<0.05)$, revealing the beneficial effect of coating application to reduce plum softening. The following order SMP > SEP > PS was observed for coatings containing antifungal agents in terms of fruit firmness control on coated plums, although the difference between coatings containing SEP and PS was not statistically significant $(P>0.05)$. HPMC-based coatings amended with PS and paraben salts had been previously reported as effective in reducing firmness loss of coated "Clemenules" mandarins [30]. According to those findings, parabens were the best agents not only for fruit firmness maintenance but also for weight loss control. This behavior is also confirmed in the present work. Therefore, it can be suggested that, in the case of plums and mandarins, the application of coatings containing parabens positively affects the relationship between fruit firmness and weight loss, leading to a significant extension of postharvest life. On the contrary, Fagundes et al. [29] reported that HPMCBW coatings containing SMP or SEP failed to control both firmness and weight loss of cherry tomatoes.

3.3. Peel Color. Color values for coated and uncoated samples after $22 \mathrm{~d}$ at $1^{\circ} \mathrm{C}$ plus $5 \mathrm{~d}$ of storage at $20^{\circ} \mathrm{C}$ are given in Table 1. All the color parameters evaluated $\left(L^{*}, a^{*}, b^{*}\right.$, $C^{*}$, and $h^{\circ}$ ) significantly decreased from those at harvest, indicating less vivid colors and a peel color change from green to red due to the ongoing ripening process during the storage period [37]. At the end of storage, coated plums maintained higher $b^{*}$ and $h^{\circ}$ values than uncoated samples (Control A) and no differences among treatments were observed in $a^{*}$ and $C^{*}$ values. On the other hand, the highest and the lowest $L^{*}$ values were recorded for the samples coated with coatings containing PS and SEP, respectively. Coatings containing parabens and PS were also tested for peel color maintenance of strawberries [38] and tomatoes [29], with relatively successful results. The differences in lightness observed in our work could be an indication of the effect of the coatings in fruit gloss. The decrease of $b^{*}$ and $h^{\circ}$ (which indicates more reddish tonalities) from the initial values at harvest was higher for uncoated (Control A) than for coated samples, demonstrating that coating applications may delay fruit ripening by creating an inner modified atmosphere in the fruit. In a similar way, Choi et al. [28] reported relative lower decreases in $h^{\circ}$ values on coated than on uncoated plums.

3.4. Internal Quality. The initial TA, SSC, and MI values of plum (values at harvest) were $1.83 \pm 0.09 \mathrm{~g}$ malic acid $/ 100 \mathrm{~mL}$, $13.67 \pm 0.19 \mathrm{~g}$ sucrose $/ 100 \mathrm{~mL}$, and $7.5 \pm 0.29$, respectively. During storage, TA decreased and MI increased consequently, whereas SSC was maintained practically constant (Table 2). Decrease in TA of plums typically occurs during postharvest storage and depends on cultivar and maturity stage at harvest. This has been attributed to the use of organic acids as substrates in the respiratory metabolism [23]. Coating application delayed acidity losses in plums compared to uncoated controls, which could be related to a decrease in weight loss and a slow-down in respiration rate and metabolic activity [39]. The higher TA of coated samples translated into 
TABLE 1: Color values of "Friar" plums uncoated or coated with hydroxypropyl methylcellulose-beeswax edible coatings containing potassium sorbate (PS), sodium methyl paraben (SMP), or sodium ethyl paraben (SEP) and stored for $22 \mathrm{~d}$ at $1^{\circ} \mathrm{C}$ followed by $5 \mathrm{~d}$ at $20^{\circ} \mathrm{C}$.

\begin{tabular}{|c|c|c|c|c|c|}
\hline $\begin{array}{l}\text { Food } \\
\text { preservative }\end{array}$ & $L^{*}$ & $a^{*}$ & $b^{*}$ & $C^{*}$ & $h^{\circ}$ \\
\hline Control $\mathrm{A}^{\mathrm{i}}$ & $25.43 \pm 0.43^{\mathrm{ab}}$ & $6.82 \pm 0.74^{\mathrm{a}}$ & $0.32 \pm 0.26^{\mathrm{b}}$ & $6.90 \pm 0.74^{\mathrm{a}}$ & $3.17 \pm 1.84^{\mathrm{b}}$ \\
\hline Control $\mathrm{B}^{\mathrm{i}}$ & $24.59 \pm 0.45^{b c}$ & $7.34 \pm 0.85^{\mathrm{a}}$ & $1.98 \pm 0.34^{\mathrm{a}}$ & $7.61 \pm 0.91^{\mathrm{a}}$ & $13.61 \pm 0.76^{\mathrm{a}}$ \\
\hline PS & $26.07 \pm 0.39^{\mathrm{a}}$ & $7.13 \pm 0.76^{\mathrm{a}}$ & $1.70 \pm 0.29^{\mathrm{a}}$ & $7.35 \pm 0.80^{\mathrm{a}}$ & $12.30 \pm 0.85^{\mathrm{a}}$ \\
\hline SMP & $24.86 \pm 0.40^{\mathrm{ab}}$ & $6.59 \pm 0.69^{\mathrm{a}}$ & $1.54 \pm 0.24^{\mathrm{a}}$ & $6.78 \pm 0.73^{\mathrm{a}}$ & $13.19 \pm 0.98^{\mathrm{a}}$ \\
\hline SEP & $23.53 \pm 0.27^{c}$ & $6.59 \pm 0.74^{\mathrm{a}}$ & $1.66 \pm 0.28^{\mathrm{a}}$ & $6.81 \pm 0.79^{\mathrm{a}}$ & $12.96 \pm 0.77^{\mathrm{a}}$ \\
\hline
\end{tabular}

Values at harvest: $L^{*}=32.64 \pm 0.67 ; a^{*}=11.66 \pm 0.57 ; b^{*}=6.10 \pm 0.88 ; C^{*}=13.49 \pm 0.55 ; h^{\circ}=23.03 \pm 2.59 ;{ }^{\mathrm{i}}$ Control A: uncoated; Control B: coating without antifungal agent. Mean values with different letters within the same column are significantly different according to Duncan's multiple range test $(P<0.05)$ (mean \pm SE; $n=20$ ).

TABLE 2: Titratable acidity (TA), soluble solid content (SSC), and maturity index (MI) of "Friar" plums uncoated or coated with hydroxypropyl methylcellulose-beeswax edible coatings containing potassium sorbate (PS), sodium methyl paraben (SMP), or sodium ethyl paraben (SEP) and stored for $22 \mathrm{~d}$ at $1^{\circ} \mathrm{C}$ followed by $5 \mathrm{~d}$ at $20^{\circ} \mathrm{C}$.

\begin{tabular}{lccc}
\hline $\begin{array}{l}\text { Food } \\
\text { preservative }\end{array}$ & $\begin{array}{c}\text { TA } \\
(\mathrm{g} \text { malic acid } \\
\left.100 \mathrm{~mL}^{-1}\right)\end{array}$ & $\begin{array}{c}\text { SSC } \\
\left(\mathrm{g} \text { sucrose }^{-1}\right.\end{array}$ & $\begin{array}{c}\text { MI } \\
\left.100 \mathrm{~mL}^{-1}\right)\end{array}$ \\
\hline Control A $^{\mathrm{i}}$ & $1.04 \pm 0.03^{\mathrm{c}}$ & $13.23 \pm 0.07^{\mathrm{a}}$ & $12.69 \pm 0.28^{\mathrm{a}}$ \\
Control B $^{\mathrm{i}}$ & $1.40 \pm 0.06^{\mathrm{a}}$ & $13.52 \pm 0.03^{\mathrm{a}}$ & $9.60 \pm 0.41^{\mathrm{c}}$ \\
PS & $1.38 \pm 0.05^{\mathrm{a}}$ & $13.68 \pm 0.12^{\mathrm{a}}$ & $9.97 \pm 0.41^{\mathrm{bc}}$ \\
SMP & $1.38 \pm 0.02^{\mathrm{a}}$ & $13.40 \pm 0.13^{\mathrm{a}}$ & $9.74 \pm 0.24^{\mathrm{c}}$ \\
SEP & $1.25 \pm 0.03^{\mathrm{b}}$ & $13.50 \pm 0.03^{\mathrm{a}}$ & $10.78 \pm 0.22^{\mathrm{b}}$ \\
\hline
\end{tabular}

Values at harvest: $\mathrm{TA}=1.83 \pm 0.09 \mathrm{~g}$ malic acid $/ 100 \mathrm{~mL} ; \mathrm{SSC}=13.67 \pm 0.19 \mathrm{~g}$ sucrose $/ 100 \mathrm{~mL} ; \mathrm{MI}=7.5 \pm 0.29 ;{ }^{\mathrm{i}}$ Control A: uncoated; Control B: coating without antifungal agent. Mean values with different letters within the same column are significantly different according to Duncan's multiple range test $(P<0.05)$ $($ mean $\pm \mathrm{SE} ; n=3)$.

MI values lower than those of control fruit, and SEP-coated samples had the highest MI. On the other hand, there were no significant differences in SSC among the different treatments.

3.5. Physiological Disorders. Physiological disorders reported for plums include mealiness, flesh browning, black pit cavity, translucency, lack of juiciness, and flesh bleeding (red pigment accumulation). These physiological disorders are reported as chilling injury symptoms (internal breakdown) and the degree of incidence depends majorly on cultivar, physiological stage at harvest, and storage conditions [32]. In this work, flesh bleeding and browning were the main symptoms observed on "Friar" plums at the end of the evaluated storage period. Both symptoms were significantly reduced by HPMC-based coatings and no significant differences were observed among coating treatments (data not shown). Severity of flesh browning was light (value of 2 within a scale from $1=$ none to $5=$ severe) and practically negligible (value of 1) in control and coated plums, respectively. Fruit flesh bleeding typically occurs as a result of anthocyanins diffusion from their original locations in the cells near the skin and/or the stone to the rest of plum flesh, and it has been attributed to tissue senescence or abnormal ripening due to chilling injury [22]. In this work, uncoated "Friar" plums showed a moderate level of flesh bleeding after storage (value of 2 within a scale from $1=$ none to 3 = severe), whereas coated samples showed no flesh bleeding (index of 1). Similar results were reported for "Autumn Giant" and "Angeleno" plums [14, 22]. These authors observed that internal physiological disorders after prolonged cold storage at $1^{\circ} \mathrm{C}$ followed by a shelf life period at $20^{\circ} \mathrm{C}$ were significantly reduced by coating application, which was attributed to the gas barrier provided by the coatings and the consequent creation of a modified atmosphere in the fruit.

3.6. Respiration Rate. The effect of the application of coatings on $\mathrm{CO}_{2}$ production rate of "Friar" plums during cold storage plus shelf life at $20^{\circ} \mathrm{C}$ is given in Table $3 . \mathrm{CO}_{2}$ production rates of uncoated plums (Control A) increased when compared with the initial value in samples stored for $11 \mathrm{~d}$ at $1^{\circ} \mathrm{C}$ plus $5 \mathrm{~d}$ at $20^{\circ} \mathrm{C}$, probably coinciding with the climacteric peak. After this storage period, $\mathrm{CO}_{2}$ production of coated samples was significantly lower than that of uncoated ones (Control A), indicating that the coatings reduced the respiration peak of the plums. On the other hand, in samples stored for $22 \mathrm{~d}$ at $1^{\circ} \mathrm{C}$ plus $5 \mathrm{~d}$ at $20^{\circ} \mathrm{C}$, although coated samples had lower $\mathrm{CO}_{2}$ production rates than uncoated plums, the differences were not significant $(P>0.05)$. As reported above in agreement with other workers, the effect of edible coatings on delaying changes related to fruit ripening, such as softening, color change, decrease in acidity, or some physiological disorders has been associated with the gas barrier exerted on the fruit surface leading to reductions in respiration rate and/or weight loss $[23,29]$. In the present work, HPMC-BW coatings significantly reduced weight loss and seemed to retard the natural physiological ripening process by reducing the initial respiration peak of "Friar" plums, which could explain their effect 
TABLE 3: $\mathrm{CO}_{2}$ production rate and ethanol and acetaldehyde content in the juice of "Friar" plums uncoated or coated with hydroxypropyl methylcellulose-beeswax edible coatings containing potassium sorbate (PS), sodium methyl paraben (SMP), or sodium ethyl paraben (SEP) and stored at $1^{\circ} \mathrm{C}$ for 11 or $22 \mathrm{~d}$ followed by $5 \mathrm{~d}$ at $20^{\circ} \mathrm{C}$.

\begin{tabular}{|c|c|c|c|c|c|c|}
\hline \multirow{2}{*}{$\begin{array}{l}\text { Food } \\
\text { preservative }\end{array}$} & \multicolumn{3}{|c|}{$11 \mathrm{~d}$ at $1^{\circ} \mathrm{C}+5 \mathrm{~d}$ at $20^{\circ} \mathrm{C}$} & \multicolumn{3}{|c|}{$22 \mathrm{~d}$ at $1^{\circ} \mathrm{C}+5 \mathrm{~d}$ at $20^{\circ} \mathrm{C}$} \\
\hline & $\begin{array}{c}\mathrm{CO}_{2} \\
\left(\mathrm{~mL} \mathrm{~kg}^{-1} \mathrm{~h}^{-1}\right)\end{array}$ & $\begin{array}{l}\text { Ethanol } \\
\left(\mathrm{mg} \mathrm{L}^{-1}\right)\end{array}$ & $\begin{array}{l}\text { Acetaldehyde } \\
\left(\mathrm{mg} \mathrm{L}^{-1}\right)\end{array}$ & $\begin{array}{c}\mathrm{CO}_{2} \\
\left(\mathrm{~mL} \mathrm{~kg}^{-1} \mathrm{~h}^{-1}\right)\end{array}$ & $\begin{array}{l}\text { Ethanol } \\
\left(\mathrm{mg} \mathrm{L}^{-1}\right)\end{array}$ & $\begin{array}{l}\text { Acetaldehyde } \\
\left(\mathrm{mg} \mathrm{L}^{-1}\right)\end{array}$ \\
\hline Control $\mathrm{A}^{\mathrm{i}}$ & $29.47 \pm 4.24^{\mathrm{a}}$ & $0.29 \pm 0.02^{c}$ & $0.18 \pm 0.01^{\mathrm{b}}$ & $20.34 \pm 1.40^{\mathrm{a}}$ & $2.14 \pm 0.23^{\mathrm{b}}$ & $0.55 \pm 0.06^{\mathrm{a}}$ \\
\hline Control $\mathrm{B}^{\mathrm{i}}$ & $20.40 \pm 0.15^{\mathrm{b}}$ & $0.98 \pm 0.05^{\mathrm{b}}$ & $0.18 \pm 0.01^{\mathrm{b}}$ & $18.74 \pm 1.46^{\mathrm{a}}$ & $1.13 \pm 0.11^{\mathrm{cd}}$ & $0.28 \pm 0.02^{\mathrm{b}}$ \\
\hline PS & $24.75 \pm 2.58^{\mathrm{ab}}$ & $1.46 \pm 0.16^{\mathrm{ab}}$ & $0.22 \pm 0.02^{\mathrm{a}}$ & $18.64 \pm 1.17^{\mathrm{a}}$ & $4.26 \pm 0.36^{\mathrm{a}}$ & $0.33 \pm 0.03^{\mathrm{b}}$ \\
\hline SMP & $18.46 \pm 1.00^{\mathrm{b}}$ & $1.40 \pm 0.16^{\mathrm{b}}$ & $0.21 \pm 0.01^{\mathrm{a}}$ & $14.53 \pm 1.17^{\mathrm{a}}$ & $0.58 \pm 0.02^{\mathrm{cd}}$ & $0.24 \pm 0.02^{\mathrm{b}}$ \\
\hline SEP & $17.04 \pm 1.21^{\mathrm{b}}$ & $1.56 \pm 0.14^{\mathrm{a}}$ & $0.24 \pm 0.01^{\mathrm{a}}$ & $18.06 \pm 1.52^{\mathrm{a}}$ & $1.39 \pm 0.26^{\mathrm{c}}$ & $0.25 \pm 0.02^{b}$ \\
\hline
\end{tabular}

At harvest: $\mathrm{CO}_{2}$ production rate $=20.02 \pm 0.71 \mathrm{~mL} / \mathrm{kg} * \mathrm{~h}$; ethanol content $=0.36 \pm 0.12 \mathrm{mg} / \mathrm{L}$; acetaldehyde content $=0.10 \pm 0.02 \mathrm{mg} / \mathrm{L} ;{ }^{\mathrm{i}} \mathrm{Control} \mathrm{A}$ : uncoated; Control B: coating without antifungal agent. Mean values with different letters within the same column are significantly different according to Duncan's multiple range test $(P<0.05)($ mean $\pm \mathrm{SE} ; n=3)$.

on the reduction of firmness loss, color change, or physiological disorders at the end of the evaluated storage period. In any case, these effects were limited and it could be expected that an improvement in the gas barrier properties of these coatings would have a greater effect on the physiological response of the fruit. Overall, the coatings containing paraben salts resulted in the lowest $\mathrm{CO}_{2}$ production rates after both storage periods tested, showing the potential of these coatings as gas barriers on plums, although the formulations might be optimized to improve the gas barrier properties. In contrast, Valencia-Chamorro et al. [11] reported an increase in $\mathrm{O}_{2}$ permeability of HPMC-lipid edible films amended with SEP and Fagundes et al. [29], working with similar coatings amended with a variety of antifungal agents, observed the highest respiration rates in cherry tomatoes coated with emulsions containing SEP. This confirms that the capacity of an edible coating to create an effective gas barrier depends not only on the coating composition and properties, but also on the commodity, cultivar, and storage conditions.

3.7. Ethanol and Acetaldehyde Contents. Fresh fruit coatings constitute a gas barrier on the surface of the fruit that reduces internal $\mathrm{O}_{2}$ and increases internal $\mathrm{CO}_{2}$ concentrations. This typically translates in an increase in ethanol and acetaldehyde volatiles that depends on the barrier properties of the coating, the commodity, and the storage conditions (basically temperature and duration). In this work, the results confirmed the creation of a modified atmosphere in coated plums stored for $11 \mathrm{~d}$ at $1^{\circ} \mathrm{C}$ plus $5 \mathrm{~d}$ at $20^{\circ} \mathrm{C}$, with higher ethanol and acetaldehyde contents than in uncoated samples $(P<0.05$; Table 3). After this storage period, treatments with HPMCBW coatings formulated with antifungal agents generally induced higher ethanol contents than coatings formulated with no agents (Control B). However, the effect of coatings on the increase of ethanol and acetaldehyde contents in the fruit was not observed at the end of the storage period, after $22 \mathrm{~d}$ at $1^{\circ} \mathrm{C}$ plus $5 \mathrm{~d}$ at $20^{\circ} \mathrm{C}$. At this time, coated samples presented lower ethanol and acetaldehyde contents than uncoated plums, with the exception of the coating containing PS, which induced higher ethanol level. These results could be related to the limited gas barrier of the coatings observed at the end of the storage period and the lack of influence of the coatings on the plum $\mathrm{CO}_{2}$ production rate (Table 3). In general, ethanol and acetaldehyde contents of uncoated "Friar" plums after $22 \mathrm{~d}$ at $1^{\circ} \mathrm{C}$ plus $5^{\circ} \mathrm{C}$ at $20^{\circ} \mathrm{C}$ were low, indicating that this cultivar does not accumulate anaerobic metabolites if proper storage conditions are used. Similar values were reported for "Angeleno" and "Autumn Giant" plums after 2 and 4 weeks of storage at $1^{\circ} \mathrm{C}$ plus a $3-5 \mathrm{~d}$ period of shelf life at $20^{\circ} \mathrm{C}[2,14]$. In these works, the application of HPMC-BW coatings significantly increased the ethanol and acetaldehyde contents in juice, but only for those coatings that had higher HPMC content (i.e., lower BW content), whereas an increase in BW content above $20 \%(\mathrm{db})$, with the consequence reduction of HPMC, significantly decreased the gas barrier of the coatings and the accumulation of these volatiles in the fruit juice to levels that were not significantly different from those of uncoated samples. However, in other fruits such as mandarins and cherry tomatoes, the use of similar HPMC-BW coatings resulted in an increase up to tenfold of ethanol in juice $[29,40]$.

3.8. Sensory Properties. Trained panelists performed a sensory evaluation to assess coating influence on external appearance, flavor (overall flavor and induction of off-flavors), and firmness of plums. At harvest, plums were evaluated as having a good external appearance $(2.0 \pm 0.2$ in a qualitative scale from $1=$ bad to $3=$ very good), a medium overall flavor ( $4.8 \pm 0.4$ in scale from $1=$ bad to $9=$ excellent $)$ that was associated with the high acidity of the fruit, absence of offflavors (value of 1 in a scale from $1=$ absence to $5=$ high presence), and a very high firmness (4.6 \pm 0.2 in scale from $1=$ very soft to $5=$ very firm). At the end of the storage period of $22 \mathrm{~d}$ at $1^{\circ} \mathrm{C}$ plus $5 \mathrm{~d}$ at $20^{\circ} \mathrm{C}$, these sensory quality attributes were scored in the range from 1.5-2.9, 4.6-5.4, 1.2-1.4, and 3.6-3.8 for appearance, overall flavor, off-flavors, and firmness, respectively. Statistical analysis showed no significant differences among treatments or storage times $(P>0.05)$ for off-flavors, firmness, and flavor of plums (data not shown). The results for flavor are in agreement with the low volatile levels detected in the fruit juice after coating application. With regard to firmness, the high values at harvest possibly contributed to maintaining high fruit firmness during storage, which could probably explain why 
the differences observed instrumentally between coated and uncoated plums were not detected by the sensory panel (Figure 2). On the other hand, plums treated with the PSbased coating were scored with the highest appearance values among all tested samples, which correlated with the highest $L^{*}$ values of these samples. In general, HPMC-BW emulsion coatings are not characterized for providing significant gloss to coated fruits such as citrus or tomatoes, mainly due to the macroemulsion character of the coating formulation $[29,30$, 36]. In the case of many plum cultivars, the epicuticular wax of the fruit surface usually forms a whitish film that reduces the natural gloss of the fruit. Therefore, differences in external appearance by the application of emulsion edible coatings were not generally significant compared to uncoated samples.

\section{Conclusion}

HPMC-BW coatings containing the food additives SEP, SMP, or PS, selected from previous research as effective coatings to reduce brown rot of plums caused by $M$. fructicola, could be of use as nonpolluting postharvest treatments to maintain fruit quality of "Friar" plums during cold storage at $1^{\circ} \mathrm{C}$ followed by a shelf life period at $20^{\circ} \mathrm{C}$. These coatings delayed the postharvest ripening process, reduced weight and firmness loss, and minimized color change and physiological disorders of the fruit. The lowest weight loss was achieved with the use of paraben salts and the highest $L^{*}$ values were obtained with the use of PS in the coating formulations. Further research is required to improve the gas barrier properties of these coatings, as well as to determine the effect of different concentrations of the food preservatives used in the present study and optimize coating composition for the best postharvest performance and maximum fruit shelf life extension. In addition, the effect of these antifungal coatings should be tested for other plum cultivars in order to broaden the spectrum of action and facilitate the commercial adoption by the industry of these coating formulations as sustainable and environmentally safe means for enhanced postharvest fruit preservation.

\section{Conflicts of Interest}

The authors declare that there are no conflicts of interest regarding the publication of this paper.

\section{Acknowledgments}

This work was partially funded by the Spanish National Institute for Agricultural and Food Research and Technology (INIA, Project RTA2012-00061-00-00) and the European Commission (FEDER program). Sule Gunaydin was a visiting student supported by ERASMUS Internship Program.

\section{References}

[1] S. Galus and J. Kadzińska, "Food applications of emulsionbased edible films and coatings," Trends in Food Science and Technology, vol. 45, no. 2, pp. 273-283, 2015.
[2] M. L. Navarro-Tarazaga, R. Sothornvit, and M. B. PérezGago, "Effect of plasticizer type and amount on hydroxypropyl methylcellulose- beeswax edible film properties and postharvest quality of coated plums (Cv. Angeleno)," Journal of Agricultural and Food Chemistry, vol. 56, no. 20, pp. 9502-9509, 2008.

[3] C. A. Campos, L. N. Gerschenson, and S. K. Flores, "Development of edible films and coatings with antimicrobial activity," Food and Bioprocess Technology, vol. 4, no. 6, pp. 849-875, 2011.

[4] L. Palou, S. Valencia-Chamorro, and M. Pérez-Gago, "Antifungal Edible Coatings for Fresh Citrus Fruit: A Review," Coatings, vol. 5, no. 4, pp. 962-986, 2015.

[5] R. K. Dhall, "Advances in edible coatings for fresh fruits and vegetables: a review," Critical Reviews in Food Science and Nutrition, vol. 53, no. 5, pp. 435-450, 2013.

[6] K. N. Turhan, Z. Ö. Erdohan Sancak, B. Ayana, and F. Erdoğdu, "Optimization of glycerol effect on the mechanical properties and water vapor permeability of whey protein-methylcellulose films," Journal of Food Process Engineering, vol. 30, no. 4, pp. 485-500, 2007.

[7] S. A. Valencia-Chamorro, L. Palou, M. A. Delŕio, and M. B. Pérez-Gago, "Antimicrobial edible films and coatings for fresh and minimally processed fruits and vegetables: A review," Critical Reviews in Food Science and Nutrition, vol. 51, no. 9, pp. 872-900, 2011.

[8] H. Karaca, M. B. Pérez-Gago, V. Taberner, and L. Palou, "Evaluating food additives as antifungal agents against Monilinia fructicola in vitro and in hydroxypropyl methylcellulose-lipid composite edible coatings for plums," International Journal of Food Microbiology, vol. 179, pp. 72-79, 2014.

[9] D. K. Das, H. Dutta, and C. L. Mahanta, "Development of a rice starch-based coating with antioxidant and microbe-barrier properties and study of its effect on tomatoes stored at room temperature," LWT - Food Science and Technology, vol. 50, no. 1, pp. 272-278, 2013.

[10] C. Fagundes, M. B. Pérez-Gago, A. R. Monteiro, and L. Palou, "Antifungal activity of food additives in vitro and as ingredients of hydroxypropyl methylcellulose-lipid edible coatings against Botrytis cinerea and Alternaria alternata on cherry tomato fruit," International Journal of Food Microbiology, vol. 166, no. 3, pp. 391-398, 2013.

[11] S. A. Valencia-Chamorro, L. Palou, M. A. Del Río, and M. B. Pérez-Gago, "Inhibition of Penicillium digitatum and Penicillium italicum by hydroxypropyl methylcellulose-lipid edible composite films containing food additives with antifungal properties," Journal of Agricultural and Food Chemistry, vol. 56, no. 23, pp. 11270-11278, 2008.

[12] W.-T. Xu, K.-L. Huang, F. Guo et al., "Postharvest grapefruit seed extract and chitosan treatments of table grapes to control Botrytis cinerea," Postharvest Biology and Technology, vol. 46, no. 1, pp. 86-94, 2007.

[13] M. B. Pérez-Gago and L. Palou, "Antimicrobial packaging for fresh and fresh-cut fruits and vegetables," in Fresh-Cut Fruits and Vegetables: Technology, Physiology, and Safety, S. Pareek, Ed., pp. 403-452, CRC Press, Taylor and Francis Group, Boca Raton, NJ, USA, 2016.

[14] M. B. Pérez-Gago, C. Rojas, and M. A. Del Río, "Effect of hydroxypropyl methylcellulose-lipid edible composite coatings on plum (cv. Autumn giant) quality during storage," Journal of Food Science, vol. 68, no. 3, pp. 879-883, 2003. 
[15] I.-H. Kim, H. Lee, J. E. Kim et al., "Plum coatings of lemongrass oil-incorporating carnauba wax-based nanoemulsion," Journal of Food Science, vol. 78, no. 10, pp. E1551-E1559, 2013.

[16] Z. Chen and C. Zhu, "Combined effects of aqueous chlorine dioxide and ultrasonic treatments on postharvest storage quality of plum fruit (Prunus salicina L.)," Postharvest Biology and Technology, vol. 61, no. 2-3, pp. 117-123, 2011.

[17] M. Guerra and P. A. Casquero, "Influence of delayed cooling on storability and postharvest quality of European plums," Journal of the Science of Food and Agriculture, vol. 89, no. 6, pp. 10761082, 2009.

[18] C. M. Cantín, C. H. Crisosto, and K. R. Day, "Evaluation of the effect of different modified atmosphere packaging box liners on the quality and shelf life of 'friar' plums," HortTechnology, vol. 18, no. 2, pp. 261-265, 2008.

[19] F. Wu, D. Zhang, H. Zhang et al., "Physiological and biochemical response of harvested plum fruit to oxalic acid during ripening or shelf-life," Food Research International, vol. 44, no. 5, pp. 1299-1305, 2011.

[20] G. A. Manganaris, C. H. Crisosto, V. Bremer, and D. Holcroft, "Novel 1-methylcyclopropene immersion formulation extends shelf life of advanced maturity 'Joanna Red' plums (Prunus salicina Lindell)," Postharvest Biology and Technology, vol. 47, no. 3, pp. 429-433, 2008.

[21] E. Reinoso, G. S. Mittal, and L.-T. Lim, "Influence of whey protein composite coatings on plum (Prunus Domestica l.) fruit quality," Food and Bioprocess Technology, vol. 1, no. 4, pp. 314325, 2008.

[22] M. L. Navarro-Tarazaga, A. Massa, and M. B. Pérez-Gago, "Effect of beeswax content on hydroxypropyl methylcellulosebased edible film properties and postharvest quality of coated plums (Cv. Angeleno)," LWT - Food Science and Technology, vol. 44, no. 10, pp. 2328-2334, 2011.

[23] D. Valero, H. M. Díaz-Mula, P. J. Zapata et al., "Effects of alginate edible coating on preserving fruit quality in four plum cultivars during postharvest storage," Postharvest Biology and Technology, vol. 77, pp. 1-6, 2013.

[24] E. Bal, "Postharvest application of Chitosan and low temperature storage affect respiration rate and quality of plum fruits," Journal of Agricultural Science and Technology, vol. 15, no. 6, pp. 1219-1230, 2013.

[25] K. Liu, C. Yuan, Y. Chen, H. Li, and J. Liu, "Combined effects of ascorbic acid and chitosan on the quality maintenance and shelf life of plums," Scientia Horticulturae, vol. 176, pp. 45-53, 2014.

[26] Z. Zhao, Y. Gu, M. Kun, and X. Li, "Effect of chitosan coating on the antioxidant enzymes and quality of 'dashi early ripening' plums," in Proceedings of the 3rd International Conference on Bioinformatics and Biomedical Engineering, iCBBE 2009, chn, June 2009.

[27] D. Paladines, D. Valero, J. M. Valverde, H. Díaz-Mula, M. Serrano, and D. Martínez-Romero, "The addition of rosehip oil improves the beneficial effect of Aloe vera gel on delaying ripening and maintaining postharvest quality of several stonefruit," Postharvest Biology and Technology, vol. 92, pp. 23-28, 2014.

[28] W. S. Choi, S. Singh, and Y. S. Lee, "Characterization of edible film containing essential oils in hydroxypropyl methylcellulose and its effect on quality attributes of 'Formosa' plum (Prunus salicina L.)," LWT - Food Science and Technology, vol. 70, pp. 213-222, 2016.

[29] C. Fagundes, L. Palou, A. R. Monteiro, and M. B. Pérez-Gago, "Hydroxypropyl methylcellulose-beeswax edible coatings formulated with antifungal food additives to reduce alternaria black spot and maintain postharvest quality of cold-stored cherry tomatoes," Scientia Horticulturae, vol. 193, pp. 249-257, 2015.

[30] S. A. Valencia-Chamorro, L. Palou, M. Á. del Río, and M. B. Pérez-Gago, "Performance of hydroxypropyl methylcellulose (HPMC)-lipid edible coatings with antifungal food additives during cold storage of 'Clemenules' mandarins," LWT - Food Science and Technology, vol. 44, no. 10, pp. 2342-2348, 2011.

[31] J. Bai, E. A. Baldwin, and R. H. Hagenmaier, "Alternatives to shellac coatings provide comparable gloss, internal gas modification, and quality for 'delicious' apple fruit," HortScience, vol. 37, no. 3, pp. 559-563, 2002.

[32] C. H. Crisosto, F. G. Mitchell, and Z. Ju, "Susceptibility to chilling injury of peach, nectarine, and plum cultivars grown in California," HortScience, vol. 34, no. 6, pp. 1116-1118, 1999.

[33] ISO 8586:2012, Sensory analysis - General guidelines for the selection, training and monitoring of selected assessors and expert sensory assessors, International Organization for Standardization, 2012.

[34] Z. Nadim, E. Ahmadi, H. Sarikhani, and R. Amiri Chayjan, "Effect of methylcellulose-based edible coating on strawberry fruit's quality maintenance during storage," Journal of Food Processing and Preservation, vol. 39, no. 1, pp. 80-90, 2015.

[35] A. Contreras-Oliva, C. Rojas-Argudo, and M. B. Pérez-Gago, "Effect of solid content and composition of hydroxypropyl methylcellulose-lipid edible coatings on physicochemical, sensory and nutritional quality of 'Valencia' oranges,' International Journal of Food Science and Technology, vol. 46, no. 11, pp. 24372445, 2011.

[36] S. A. Valencia-Chamorro, M. B. Pérez-Gago, M. Á. del Río, and L. Palou, "Effect of antifungal hydroxypropyl methylcellulose (HPMC)-lipid edible composite coatings on postharvest decay development and quality attributes of cold-stored 'Valencia' oranges," Postharvest Biology and Technology, vol. 54, no. 2, pp. 72-79, 2009.

[37] F. Guillén, H. M. Díaz-Mula, P. J. Zapata et al., "Aloe arborescens and Aloe vera gels as coatings in delaying postharvest ripening in peach and plum fruit," Postharvest Biology and Technology, vol. 83, pp. 54-57, 2013.

[38] L. C. Garcia, L. M. Pereira, C. I. G. de Luca Sarantópoulos, and M. D. Hubinger, "Selection of an Edible Starch Coating for Minimally Processed Strawberry," Food and Bioprocess Technology, vol. 3, no. 6, pp. 834-842, 2010.

[39] N. B. Gol, P. R. Patel, and T. V. R. Rao, "Improvement of quality and shelf-life of strawberries with edible coatings enriched with chitosan," Postharvest Biology and Technology, vol. 85, pp. 185195, 2013

[40] A. Contreras-Oliva, C. Rojas-Argudo, and M. B. Pérez-Gago, "Effect of solid content and composition of hydroxypropyl methylcellulose-lipid edible coatings on physico-chemical and nutritional quality of 'Oronules' mandarins,' Journal of the Science of Food and Agriculture, vol. 92, no. 4, pp. 794-802, 2012. 

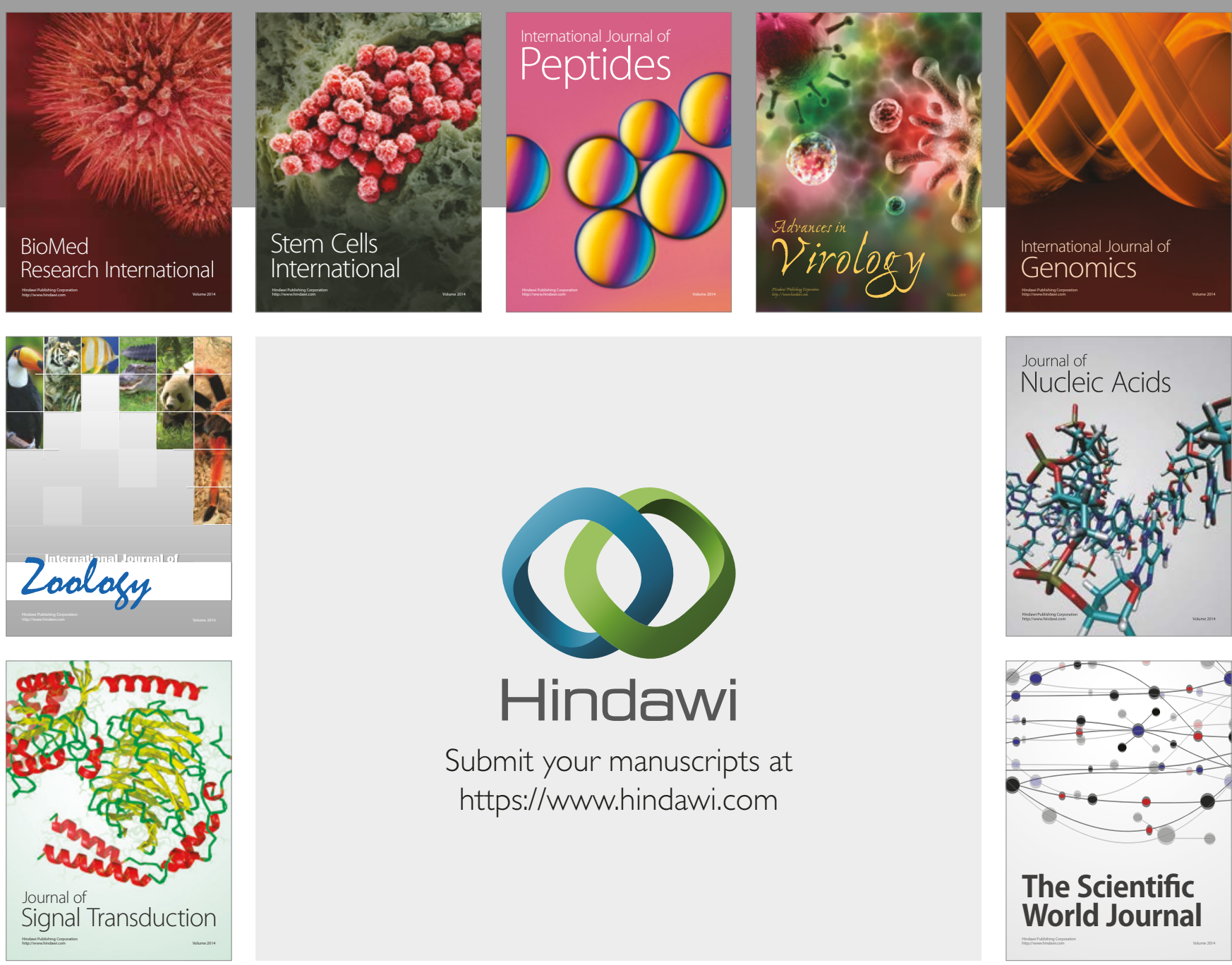

Submit your manuscripts at

https://www.hindawi.com
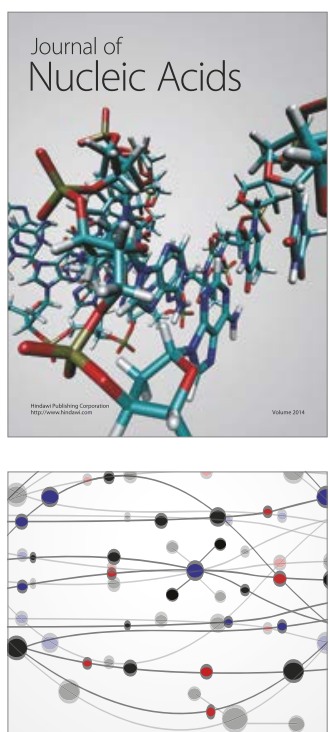

The Scientific World Journal

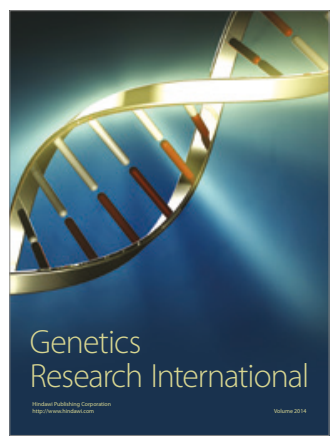

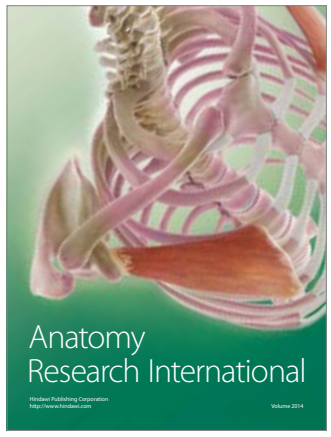

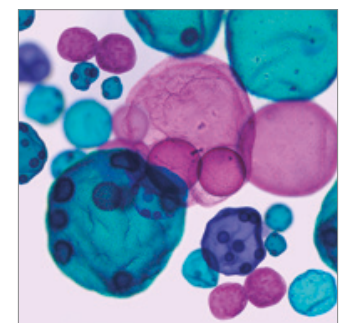

International Journal of Microbiology
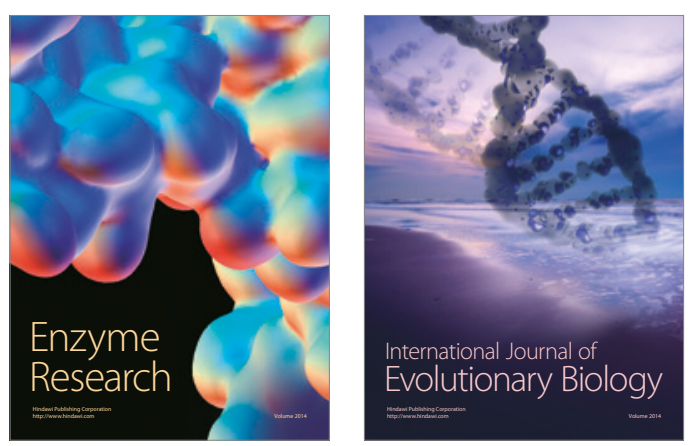
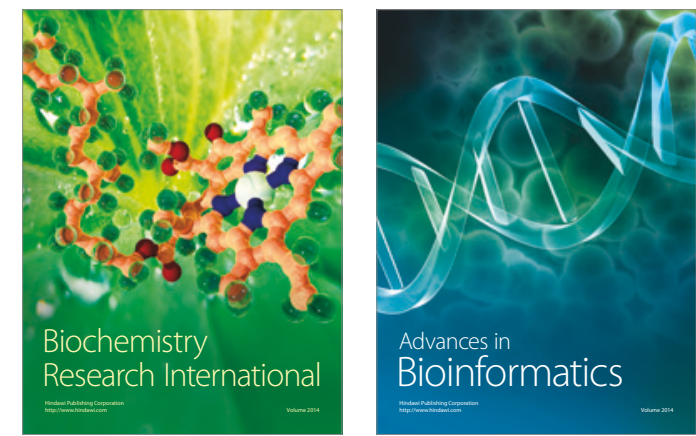

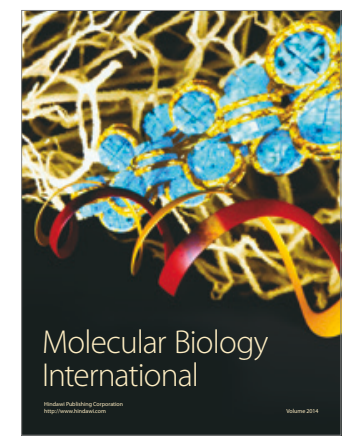

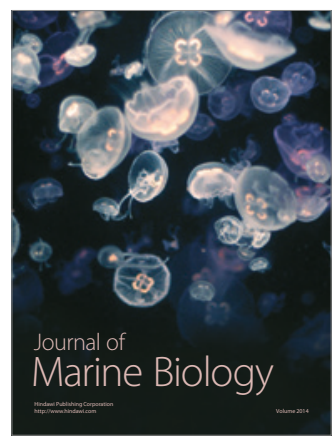

